\title{
OUR CITY IS OUR RESPONSIBILITY: Improving the Quality of Bandung's City Open Space through Community Participation
}

\author{
Lucy Yosita, Rr. Tjahyani Busono, R. Irawan Surasetja, Rd. Diah Sri Hartati \\ Architecture, Universitas Pendidikan Indonesia, Bandung, Indonesia
}

\author{
corresponding author: lucyyosita@upi.edu \\ tjahyanibusono@upi.edu \\ irawansurasetja@upi.edu \\ arstropis2019@gmail.com
}

$\begin{array}{ccrr} & \text { Article History: } \\ \text { Received: } 22 \text { February } & \text { Revised: } 5 \text { Maret } & \text { Accepted: 4 April } & \text { Available online: } 11 \text { April } \\ 2019 & 2019 & 2019 & 2019\end{array}$

\begin{abstract}
This research analysis the usage of various open spaces in Bandung City, and identifies influence of community participation on toward design of open spaces in local area in Bandung. Bandung get 2 times of Adipura Charter Again in 2015, 2016, 2017. The result of analysis indicates City Park as one of central open space in Bandung has been changing in design to be more green, comfortable, and complete with various landscape furniture, and encourage various activities than before. The design of City Park is also impressing to design of several local open spaces as product of PIPPK program, as one of the Mayor of Bandung program to developing Bandung City since 2015-now. Open spaces on local area for example in a village or district, is vary from : court yard, sport field, children playground, and garden as product of community participation. From quantitative analysis the activity value is $93,39 \%$, so it could be conclude that community 's participation level is good and also the corruption level has been declined. But it is should be needed about increasing allocation for training sector which still on $5,08 \%$ from tottaly fund.
\end{abstract}

Keyword : Open space, Community participation, Sustainable city

\section{Background of the Study}

Balaikota Building ("gemeente huis") where The Bandung Government Center located this time is a building that bounded by Merdeka Street, Wastukencana Street, Aceh Street, and Perintis Street. The building is one of old building in Bandung. Before the building was built, in the location of the building there was a Coffee Shed (Koffie Pakhuis) belonged to Adries de Wilde $(1781-1865)$, an owner of land and an resident of Priangan's assistant in 1812. The Coffee Shed was built in 1819 while all of coffee gardens in Priangan branced out in $18^{\text {th }}$ century. The Coffee Sehd was one of eight new building in Bandung. In 1924, the Coffee Shed was break down. Instead, set up the town hall was designed by architect EH de Roo, the founding of the town hall is related to the status of the city of Bandung as the municipality since 1906. This rectangle building located near Braga Street - the center of economic activities at that time. Some of supporting by building which has existed too before it, for example Javasce Building (1909), Katedral (1921), and Bethel Church (1925).

In 1935, in a row of Bandung City's branch out, Balaikota Building was getting wider with an extra building (new building) behind it, EH de Roo was still be the architect. He designed the building with "art deco" concept so the building looks more modern. The new building faced Pieter Sijthoffpark (now Taman Dewi Sartika). The roof's shape looks flat so the building called Gedung 
Papak. Since 3 years at least in new lead of Mayor there was some changes in this observation object. According to the layout, Balaikota Building is U-shaped with the center in the central of the landscape. It analogize that people centralized socially.

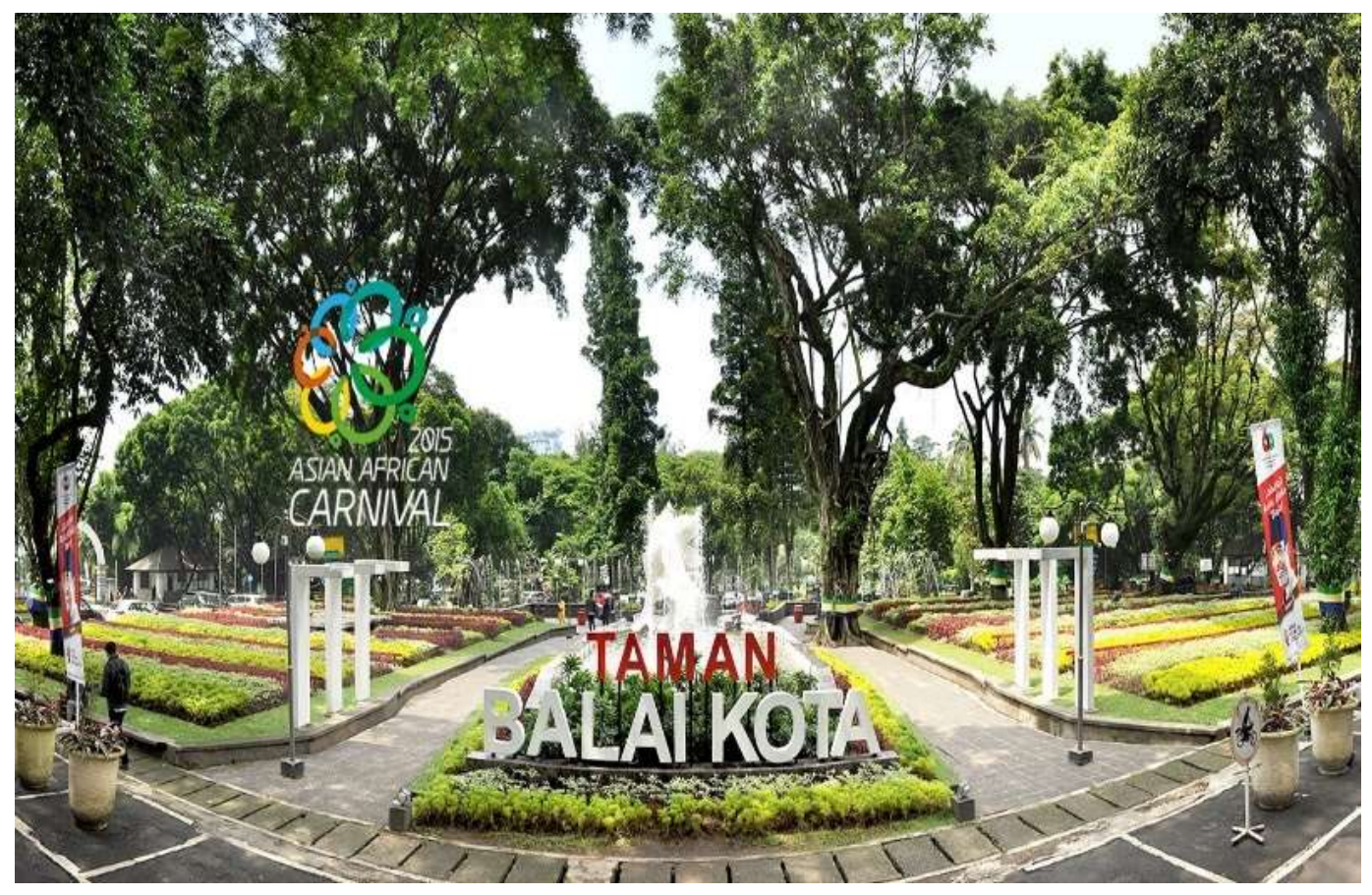

Figure .1 Conditions Bandung City Hall Park now, look more airy, lively and has a complete tread elements (landscape furniture) more complete.

The main purpose of this research is to analyzing the changes in urban open spaces in Bandung city and see how the effect of public participation in the planning open space especially in at least in 3 years $(2015-2018)$. As we saw that to many changes in the open space di the city center, but we do not know yet. The question research from the description of the background is :

1. How is the change of urban open space in Bandung ?

2. Is there the harmony aswell as synchronize between open space planning in the uptown and in the downtown?

3. Has the development open space involved the local part and by concept the community participation?

4. What should next to be done for developing and evaluation Bandung open space planning in the future ? and

5. How is the defiance and the opportunity?

\section{Research Method}

This research is will be using descriptive survey method, because this research has the goal to mapping phenomena about usage of open space in central city and local area of the city in Bandung. Meanwhile structure of methodology of this research is refer to Krier (1997), that architecture is a actually cultural phenomena and not just physical reality, therefore architectural space is contains of static space and dynamic space. The strength of this method is on the result of the research which getting by recording activity and direct survey analysis. As Carr (1992) stated on his theory that the best way to understanding open space is by doing direct survey to the location, spare time to looking for how the usage of open space, and then also recording what our feeling when using this object of research. Time design which was used in this research is by cross sectional research in which giving snapshot phenomena on 2015-2018.

The tools of this research is using several way, such as : Guidance of observation, Guidance of interview, and documentation. Observation is being use to mapping spatial composition and benefit of space based on space-time and user. Meanwhile in dept interview, observation and documentation is being used to reconstruction design of spatial space in location of this research. In depth interview is also being used to collecting primary data about the role of open space in 
context of holding community activity as user of the open spaces. To clarify all process of observation is also using several tools of documentation to recording how al visual condition of this research.

\section{Result and Discussion}

\subsection{The Change of Open space design Taman Balaikota and the Usage since the changing of New Mayor of the City.}

The change that occured in the Park City Hall can be seen in the picture, for example: (1). It has the type and amount of vegetation that is more, (2). It has elements of landscape more complete, such as a park bench, a circulation path that is more dynamic, garden lights, bins, and water elements in the landscape better planning, and (3). It has more flexible access from many points . The landscape elements used by the citizens at the city hall are: bench, pedestrians, pools, children's playgrounds and Bandros cars that are sometimes parked on site. It was found at one time observation on holiday that six benches located on the east side were used at least by 8 people up to 14 people. The activities can vary, such as sitting, chatting, reading or lying down. In one bench, there was at least one person sitting up to three or four people if they are with children.

Meanwhile, the number of pedestrian on the east side in every five minutes could be 6 to 10 people passing by. It means that if in average there were 8 people passing by in an hour, then there would be about 90-95 people passing in pedestrian at holiday time in an hour. Their activities can vary, for example: walk from the south side to the north or east, sit in the garden, accompany the children to play in the fitness arena in the city hall park, in the water pool on the north side, or at the clear river on the east side. Meanwhile, parked Bandros cars were often used for photo session, in which every 10 minutes there must be one to three people taking pictures with the car.

In average, the number of visitors of Bandung-Park City Hall on holiday based on the field survey were: 50 children, $26-30$ parents, $15-20$ teenagers, 7-8 officers, and about 8 traders. The main activities are: walking, cycling, taking pictures, reading, chatting, playing roller skating, and accompanying children to play. Meanwhile, another interesting furniture landscape element at this location is a water pool on the north side, which has only been operating for a few months. Within an hour of observation, it was found that there were 70 children, about 20 teenagers, 35-45 parents, 3 security guards and 3 janitors.

Changes visible activity with respect to changes in design and completeness of the above elements are:

1. There are more people using Taman Balai Kota (Bandung-Park City Hall).

2. Activities in the park city hall become more varied for example: sitting, taking a rest, and another recreation activity such as taking pictures, reading, chatting, sports and others.

3. The nature of ownership ("sense of belonging") making community more stronger to preserve quality public open space of the city.

4. The public open space that has been better then be one means anyway to change cultural attitudes fortified society (social attitude) toward the better, with a better possibility for use of urban space to: strengthen socialization, closer to nature, reading, enjoying the beauty of public spaces and so on. At the end of these things also contribute to the development of behavior (attitude development) urban community. anyway to change cultural attitudes fortified society (social attitude) toward the better, with a better possibility for use of urban space to: strengthen socialization, closer to nature, reading, enjoying the beauty of public spaces and so on. At the end of these things also contribute to the development of behavior (attitude development) urban community.

5. Developing public participation for an active role of urban development. For the latter is supported by the Mayor who open themselves to the development of information, for example : center collaboration (cooperation center), website, twitter, facebook and so on. Participation in development and research are also more accesible. 

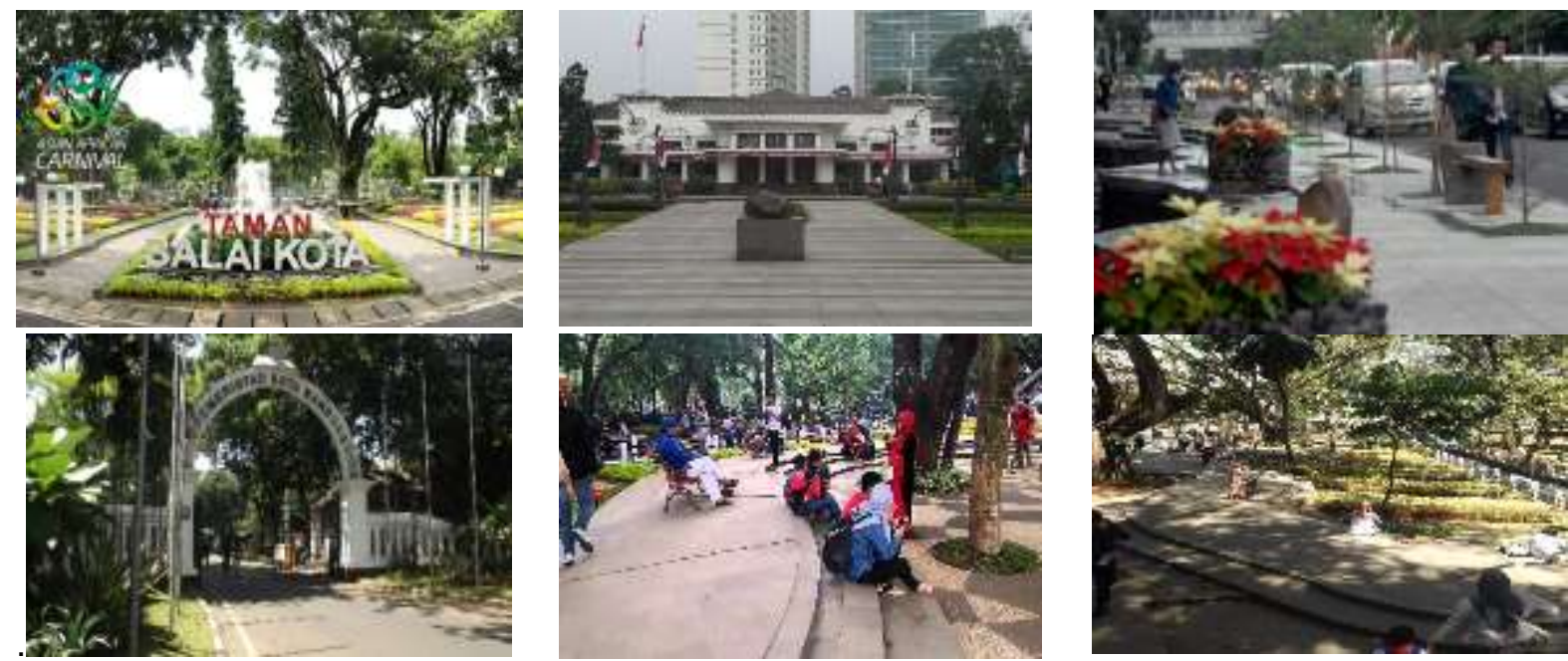

Figure. 2 Conditions Bandung City Hall Park today, looks more beautiful, comfortable dynamic, lively and has a complete tread elements (landscape furniture) more complete so that people are more comfortable using everyday even though this is an administrative formal urban park.

From the Carmona theory (2003), in his book - Public Places-Urban Spaces stated that on the components environment that can successfully planning is learned that the sustainable city has higher requirements and detail about condition of its aspects. Then to the value on the local environment requires an assessment as well. If seen the local environments in Bandung City, it is important to be compare with the quality of environment in the urban center as well. It is interesting to observe a Mayor of Bandung Programs that known as "Program Inovasi Pembangunan dan Pemberdayaan Masyarakat" (PIPPK), these program were launched since the beginning of 2015 with goals of equitable outcome of the development and still to be continued until now. This program has focus on development and community empowerment for example : Developing infrastructure and public facilities, greening program, empowering community, etc

\subsection{Analysis program PIPPK as a program that has improved physical and social function for local environtmental urban.}

PIPPK programs included one of new programs for Bandung City, in 2015 successful absorbed as much as 93,39 percent for total of budget allocated Rp.200 billion. Of the 30 subdistrict in Bandung City, Sub district Sumur Bandung and Sub district Babakan Ciamis be the lowest sub district in absorption PIPPK. PIPPK program aims to equitable development so that the physical or social and economic community not only concentrate in the central, or only the partially in certain parts. To realizing this development we must have a special concept which aims at building $1.561 \mathrm{RW}$ the feels the benefits and the result was a concept equality by all resident of Bandung.

Besides of that, the concept of the development power is not only monopolized by the government, the society not only be the private sectors but also to be active participants with strategies of community participation which organizes the development plan. And the concept is also concept of sharing that is means not only one such as group like RW but also young youth, mothers, and others so that all elements of society can become more empowered to improve, maintain physical and non-physical environment. In this way more possible on the theory Enyedi (2004), that is various phenomena of social segregation will be overcome in addition will also allow the implementation of a more sustain in the future. In this way also the uniqueness of their communities can be raised that will contribute to physical planning. According to the Secretary of Bandung, Yossi Irianto said PIPPK 2015 implementation has been realized for Rp.213.551.758.523,- of the total budget Rp.228.661.346.556, - or be absorbed by 93.39 percent.

According to Seymour M Gold (1980) in his book Recreation Planning and Design state that one a day, there are three parts of usage time: subsistence time, where time used to do the daily activities such as eating, drinking, and sleeping. Then existence time, where the time used to perform work related to professions such as work or study, and leisure time is the time used for activities outside activity existence and subsistence. In theory, in a day there is a time called leisure, time, where we could do recreation activities. Open space itself, according to Frederick 
Giberd (1970) in his book titled "Civic Center" served as the center of community 's activities. So, open space actually is not only for recreation, but also for another daily activities, but are not formal. For example people can use the open space for read a book, eat some snacks or drink.

In a more global condition, social conflict happened more often so there would be more obstacle in social integration (Enyedi : 2004), factors that influence including (1). Poverty (2). Migration (3). Houses development and city developing (4). Spatial Segregation. According to those factors, community's participation isactually an important thing in sustainable city development since community 's participation can anticipate more obstacle and developing many programs that support sustainability of a city.

Characters that has to pay more attention in designing a modern city according to Carmona (2003) there are : (1) Healthier building (2) Healthier environment (3) Transportation facility that more comfortable (4) Architecture design philosopy (5) Attitude to the past. So it can be concluded that public space is affected by physical factor, non physical factor, and regulation. A healty open space isn't enough, it should contains a good attitude and insightful for a long time to grab the "Success Modern City" tittle. Matther Carmona (2003) in her/his book Public Places-Urban Spaces said about components that determine environment design, including :

Table 1_The Determinant Components Environment Planning (places) successful

\begin{tabular}{|c|c|c|c|}
\hline KEY ATTRIBUTES & \multicolumn{2}{|c|}{ INTANGIBLE } & \multirow{2}{*}{\begin{tabular}{l}
\multicolumn{1}{c}{ MEASUREMENTS } \\
Crime Statistic \\
Sanitation Rating \\
Building Condition \\
Environmental Data
\end{tabular}} \\
\hline $\begin{array}{l}\text { COMFORT } \\
\text { IMAGE }\end{array}$ & $\begin{array}{l}\text { Safety } \\
\text { Charm } \\
\text { History } \\
\text { Attractiveness } \\
\text { Spirituality }\end{array}$ & $\begin{array}{l}\text { Sittability } \\
\text { Walkability } \\
\text { Greeness } \\
\text { Cleanliness }\end{array}$ & \\
\hline $\begin{array}{ll}\text { ACCES } & \text { AND } \\
\text { LINKAGE } & \end{array}$ & $\begin{array}{l}\text { Readability } \\
\text { Walkability } \\
\text { Realibility } \\
\text { Continuity }\end{array}$ & $\begin{array}{l}\text { Proximity } \\
\text { Connectedness } \\
\text { Convenience } \\
\text { Accessibility }\end{array}$ & $\begin{array}{l}\text { Traffic Data } \\
\text { Mode Split } \\
\text { Transit Usage } \\
\text { Pedestrian Activity } \\
\text { Parking Usage Pattern }\end{array}$ \\
\hline $\begin{array}{ll}\text { USES } & \text { AND } \\
\text { ACTIVITY } & \end{array}$ & $\begin{array}{l}\text { Realness } \\
\text { Sustainability } \\
\text { Specialness } \\
\text { Uniqueness } \\
\text { Affordability } \\
\text { Fun }\end{array}$ & $\begin{array}{l}\text { Activity } \\
\text { Usefulness } \\
\text { Celebration } \\
\text { Vitality } \\
\text { Indigenousness } \\
\text { "Homegrown" quality }\end{array}$ & $\begin{array}{l}\text { Property value } \\
\text { Rent Level } \\
\text { Land-use pattern } \\
\text { Retail sales } \\
\text { Local bussines Ownership }\end{array}$ \\
\hline SOCIALIBILITY & $\begin{array}{l}\text { Cooperation } \\
\text { Neighbourliness } \\
\text { Stewardship } \\
\text { Pride } \\
\text { Welcoming }\end{array}$ & $\begin{array}{l}\text { Gossip } \\
\text { Diversity } \\
\text { Storytelling } \\
\text { Friendliness } \\
\text { Interactivity }\end{array}$ & $\begin{array}{l}\text { Street life } \\
\text { Social networks } \\
\text { Evening use } \\
\text { Volunteerism } \\
\text { Number of women } \\
\text { Children and elderly }\end{array}$ \\
\hline
\end{tabular}

Community 's participation can be built in the formal way or the informal way. In the formal way, it could be some instructions from authorized side, example: government, NGO, etc. While in the informal way, it could be :

- Forum about city planning

- Round table discussion

- Training that prospective

- Discuss about important local issues

- Make a report for public

- Sustainable training.

At least, holistic urban design has to notice these aspects :

- City planning has level of caring that higher for people

- City planning produce valuing space

- City planning match with the reality

- City planning has design process that sustainable 


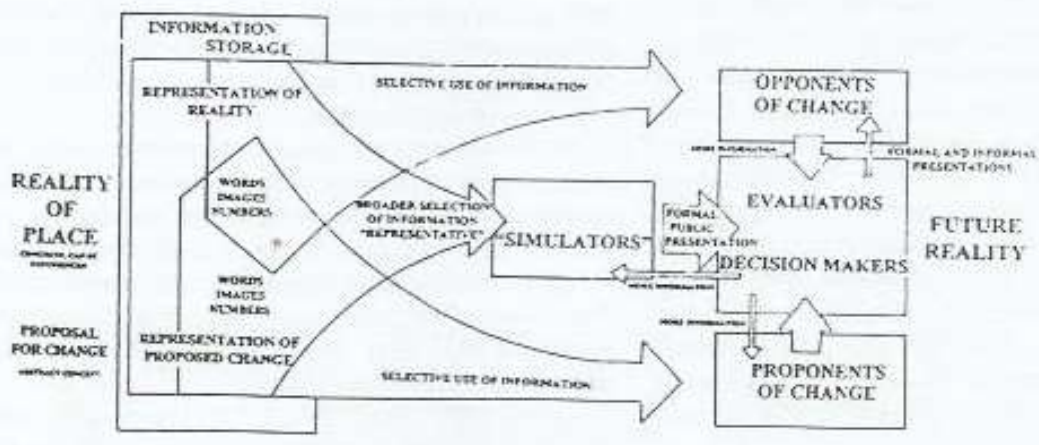

Chart 1 The diagram above is explaining about how to improvement through proposes of change that need better equilibrium although the problems increases. Every development subject need sustainable evaluation.

The conclusion from the diagram above is that an open space management process that developing in a city is should be balance between proposal of change with the problems that happened. The actor of development must have ability for select, manage, and simulate the solution. So the result would be more optimal. When analyzed, this is because the local planning management better be able to monitor the achievement of the results in more detail and detail. Then how the results obtained, through program, PIPPK Award was achieved Sub District Panyileukan, Cibiru, Rancasari, as well as the Bandung Wetan Babakan Ciparay, being the level achieved by the Village Ancol Village, Dunguscariang, Jatihandap, Jamika and Sukagalih. Then the reward is given an award given to the 10 district and 10 village heads to be trained to Singapore. It is, namely the provision of reward and punishment in accordance with the theory of Seyeda (2013), the system can spur better performance again. Meanwhile, according to Willey (2009), stated that it is necessary for community and environmental experts to have more attention to the relationship between space-linkage, this is to keep the environment comfortable (liveable) and unavoidable conflicts. It is also mentioned to him that should change adaptation must be balanced space, between : (1) Live work,(2). City branding dan (3). Imaging.

Table 2. Analysis to design of open Spaces and the usage of open space as the result of PIPPK Program

\begin{tabular}{|l|l|}
\hline The result of PIPPK program & \multicolumn{1}{c|}{ Assesment } \\
\hline $\begin{array}{l}\text { The example result of improvement the open space } \\
\text { in Cibolerang area, Subdistrict Margahayu Utara, } \\
\text { District Babakan Ciparay, Bandung City. Can be } \\
\text { seen that the open space be well taken care off, } \\
\text { directed in term of circulation, interested with } \\
\text { matching paint and had more brighter color and } \\
\text { more dynamic, and also applied nursery } \\
\text { reforestation to maintain the quality of the } \\
\text { environment. }\end{array}$ & $\begin{array}{l}\text { It is can be seen also in this Cibolerang open space } \\
\text { in addition repaired with participatory planning } \\
\text { therefore also can be able to encourage } \\
\text { participation-active public participation in the } \\
\text { settlement. The society can use it for children for } \\
\text { playing because it provide of complementary new } \\
\text { landscape furniture as game tools in this open } \\
\text { space. At certain time this open space is used for } \\
\text { the health service for Posyandu, and then in } \\
\text { addition using for their daily activities, such as : } \\
\text { sitting, socializing, or exercising. }\end{array}$ \\
\hline
\end{tabular}

6 | Lucy Yosita, Rr. Tjahyani Busono, R.Irawan Surasetja, Rd. Diah Sri Hartati 


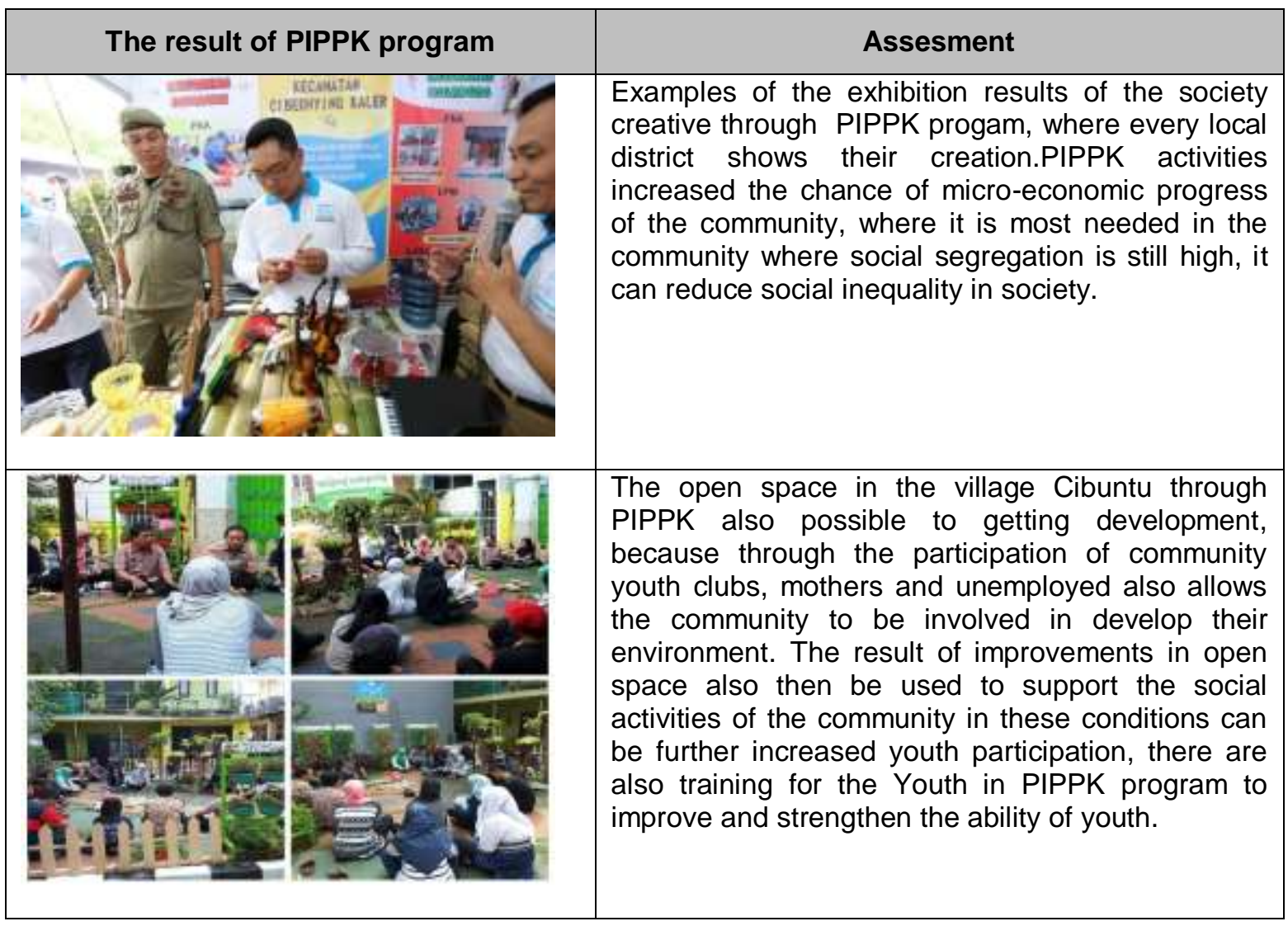

Can be seen in the analysis in section 6 levels seen that the various elements of society more positive activity in open spaces, both youths, housewives and children will be able to provide social value which further increase the economical value. About how the effects of space public in the city center to the design of public spaces at the local level can then be understood in the analysis in table 3 above. Only in this case what is needed is the foresight of local government officials to determine the uniqueness of the local administrative area. If comparing, between Margahayu and Cibuntu open spaces as focus of this comparison study between central public space and local open space, it also can be analyze by using Carmona theory (2013). There is conclusion that about 3 aspects is good: (1). Acces and Linkage, (2). Uses and Activity and (3). Socialibility. But about comfort and image still should be get improving, because by the time facility is need maintenance. This is should good commitment between politician and society to keep spirit on improve their environment, by increasing their sense of belonging.

Based on physically can be judged that there contextual between the design of Bandung City Hall Park and open spaces in the area Cibolerang, Village North in the Village Margahayu Cibuntu. Design of open space in the neighborhood of the community look more dynamic but still lacks clarity of activity. Regulation about function on their own living environment contained in article 40 of Law No. 39/1999 on Human Rights. Place of residence must be healthy, comfortable and aesthetically beautiful. There are actually requirement to reduce pollution in the environment according to Blower (1995): (1) Preventing the production of pollution at the source core, (2) Managing pollution discharge, and (3) Reducing impact of pollution. These things are the result of a growing city population.

The most significant is actually more interesting to analyze the topic of this analysis is the role of youth development in which youth are the future leaders will be, where the youth has the energy and ideas that are still likely will push social society to the level of progress of the nation is significant. However it is need sustainable process on developing their ability, by good programme, good training, etc. When viewed on a social media Bandung Karang Taruna, it is known that PIPPK these programs involve the role of youth. There is a change in which the public is not too apathetic to development programs for community participation approach allows results that match the wishes and needs of local communities and also minimize the level of corruption in the practice implementation. 
According to Blower (1995), stated that sustainable development needs to consider the capacity of the earth and also degradation and also how to prevent it, so that the system can be sustaining and improving productivity (environment capacity). It is also necessary for the sustainable development of minimalize gap between the rich and the poor so that development can take place on the social good. Meanwhile, according to Kusumawijaya (2006), stated that the urban agglomeration occurs as encouraged by the industry's is actually needs to achieve economies of scale, as well as due to the pressure of population growth and profit-mobility social mobility culture offers.

Then, according to Gottman in Marco (2006) also mentioned that it is important to shift the discussion to the socio-cultural discussion of spatial functional. He defines that a megalopolis as a stretch of urban and suburban virtually concatenated have large concentrations of people with an average density relatively high in a region that spans related to each other by means of rapid communication. The nature of the leader of the city that is very open at this time appealing to encourage researchers to be able to analyze how changes in the city, both physically and socially. Presumably, their up-dating news regularly from the Mayor of Bandung for any progress or urban problems, on social media more favorable conditions for the community $s$ of Bandung to both maintain, develop, build and preserve their beloved Bandung.

\section{Conclusion and Suggestion}

From analysis above can be get conclusion and suggestion for evaluating aplication of participatory planning on designing open space through Bandung and around in context improvement of open spaces through Bandung City. It is mainly evaluate about condition and behaviour on open space in 1 years (2015-2016), this is the conclusions :

1. Open spaces in uptown and downtown Bandung City has became a better and equitable improvement. One of the indicators is community activities level in fixing open space was also became better, they feel more comfortable there due to the quality that looking nice and has been improved.

2. PIPPK is a program focus on increasing participatory planning on local level. From data the activity value is $93,39 \%$, so it could be conclude that community 's participation level is good and also the corruption level has been declined.

3. Activity allocation in infrastructure tools improvement is $35,61 \%$, it means that should be a proportion improvement. If in the first phase the value reach $43,44 \%$ it would be appropriate, but in the next time it has to be balanced with: youth training activity, unemployment, dan housewives that have a lot of free time which can be used for social activities and repair the environment.

4. City parks design are good, but it has to be fixed sustainably such as : housing backlog conditions reach lack of 13.500 .000 houses in all over Indonesia, transportation solution that became more difficult (crowded), about social problem and crime value that still reach a high percentage.

5. Development approach is good, it has been reached so much aspects such as: youth, housewives, and early childhood. Those can be social modal that would sustain the development for a long time.

6. Allocation for community training on precentage $5,08 \%$ is should be increase with unemployment value that still reach a high percentage 107.565 peoples (Data of Disnaker, Bandung).

7. Collaboration with education institution is needed, through research and dedication to the community s. This is such an important thing because actually there are so much research fund in some campuses but it still hasn't connected and sustained yet with development programs. So the government should be more open to keep looking for education institution roles. It would be such a helpful activity for development in Bandung and encourage community participation because students from campuss are actually more probable to have good relation with community.

\section{Acknowledged}

Authors acknowledged RISTEK DIKTI (Grant for Penelitian Strategis Nasional Indonesia (PSNI)). Authors also thank to Fitri Audria Gunawan and Viko Millenia from Departemen 
Pendidikan Teknik Arsitektur of Universitas Pendidikan Indonesia for their help in assisting this research.

\section{References}

Altman, Irwin (1980). "Culture and Environment". California: Brooks/Cole Publishing

Blower, Andrew (1993), Planning for Sustainable Enviroment, Earthscan Publication Ltd, London

Cooper, Rachel (2009), Designing Sustainable Cities, Willey-Blackwell, Singapore.

Carmona, Mathew (2003), Public Places-Urban Spaces, Architectural Press, Kent, UK.

Carr, Stephen (1993), Public Space, Cambridge University Press.

Enyedi, Gyorgy (2004), Public Participation in Socially Sustainable Development, Unesco, Hungaria.

Habraken, N. John (1978): "General Principles about the Way Built Environment Exist". Massachusetts.

Hanan, Himasari (2011), Pedestrian Ways, informalities and Urban Spectacles, Procedia Behavioral Science, Elsevier.

Handler, Benjamin A (1970), "System Approach to Architecture", American Elselvier, New York.

Kusumawijaya, Marco (2006), Kota Rumah Kita, Borneo Publications, Jakarta, Indonesia.

Rapoport, Amos (1977): "Human Aspecs of Urban Form: Towards a Man Environment Approach to Urban Form and Design". New York, Oxford University Press.

Permana, A.Y. (2012), Eco-Architecture sebagai Konsep Urban Development di Kawasan Slums dan Squatters Kota Bandung, Paper on National Seminar "Pengelolaan Sumberdaya Alam dan Lingkungan : Meningkatkan Peran Strategis Pengelolaan Sumberdaya Alam dan Lingkungan dalam Pembangunan Berkelanjutan " PSIL Pascasarjana Universitas Diponegoro, Semarang.

Sastra, AF, Hamid D, Yosita, L (2018), Improvement Value of Urban Kampong Based on Community Potential in an Architectural Perspective Study, Proceedings The 2nd AASEC Conference, IOP Publishing, Bandung.

Soemarwoto, Otto (1997)., Ekologi, Lingkungan Hidup dan Pembangunan., Penerbit Djambatan., Jakarta.

Soheila, Seyeda (2013), The Role of Citizen Participation in Sustainable Development, International Research Journal of Applied and Basic Sciences, Science Explorer Publications

Yosita, Lucy (2013), Analysys of Movement of Dynamic Indonesia Megacities After 2010, Procedings International Seminar "Asian Urbanism and Beyond", Chinesse University of Hongkong, Hongkong, China.

Yosita, Lucy (2015), Strategi Perencanaan Perumahan pada Era Kontemporer, Dee Publish, Yogyakarta, Indonesia.

Zeisel, John (1981): "Inquiry by Design, Tools for Environment, Behaviour Research". California; Cambridge University Press. 